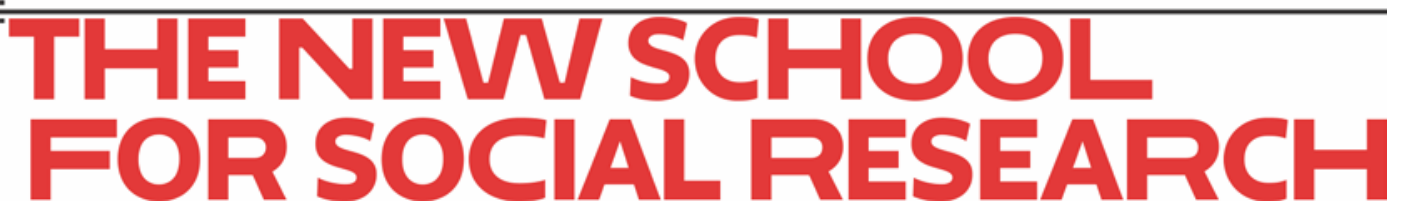

Duncan Foley

Socialist alternatives to capitalism I: Marx to Hayek

February 2017

Working Paper 05/2017

Department of Economics

The New School for Social Research 


\title{
Socialist alternatives to capitalism I: Marx to Hayek
}

\author{
by Duncan K. Foley*
}

\section{Utopian and scientific socialism}

While philosophical speculation on the design of social, economic, and political institutions goes back at least to Plato (and perhaps further to Hammurabi), I will start this discussion at the end of the eighteenth century, in the radical and romantic response to the French Revolution. The nascent Industrial Revolution, the eclipse if not the collapse of the religious monopoly over discussion of the social and political "good", the enormous energies of mass politics unleashed by the bourgeois revolutions, and Enlightenment theories of political economy and political theory prompted a surge of radical criticism of existing social institutions and speculation on their future evolution.

An important and persistent strain in this revolutionary discourse viewed the demonstrated (though not yet fully exploited) increases in productive power unleashed by the Industrial Revolution as offering for the first time in human history the possibility of creating a human society freed from material poverty and even scarcity of basic goods. "Perfectibilists" such as William Godwin (see Foley, 2006, ch 2) argued for a rational reconstruction of social institutions to realize these possibilities, engendering an intellectual reaction from figures such as Thomas Malthus, who proposed to demonstrate "mathematically" that population growth would doom such projects.

${ }^{*}$ Leo Model Professor, Department of Economics, New School for Social Research, 6 East 16th Street, New York, NY 10003 (foleyd@newschool.edu) and External Professor, Santa Fe Institute. This talk was prepared for lectures at the Havens Institute at the University of Wisconsin, Madison, April 6-7, 2011. 
"Really existing" capitalism proved quite capable of achieving enormous increases in social productive powers, but fickle in the distribution of the resulting gains. Industrial entrepreneurs accumulated fortunes, a growing "middle class" representing a significant minority of the population found niches that provided a degree of security and comfort in the exploding division of labor, but by and large productive workers found themselves subject to fierce competition for jobs that sharply limited their economic gains. These disparities were dramatic enough in the few parts of the world experiencing industrialization to interest many, particularly of the middle classes, in projects for a more rational and egalitarian organization of social production and income distribution.

"Radical" movements demanding political reform of corrupt national systems, the universal extension of civil and political rights, free trade, republican forms of national political organization, and the like achieved major gains in countries like France and England. On the fringe of this basically bourgeois democratic radicalism appeared a flowering of theoretical writing on the possibility of reorganizing the industrial division of labor on "socialist" principles of rational allocation and egalitarian distribution. In the same period there were numerous small-scaled "experiments" in the form of local communities seeking to organize industrial production in alternative ways. The history of these experimental communities, some of which lasted quite a long time, is an instructive lesson in the power of capitalist social organization to encapsulate and absorb economically deviant behavior. Neither the theoretical nor the experimental side of this socialism achieved much headway compared to the awesome force of capitalist accumulation in fostering proletarianization, urbanization, and globalization in line with its own logic of the pursuit of profit.

Karl Marx's political thought centered on the unfinished business of the French Revolution, which had transformed the landscape of European politics, weakening the monopoly on power of ancien régime landed interests and revealing the nascent strength of the industrial and financial bourgeoisie. The democratic and egalitarian ideological impulses unleashed by the revolutionary moment pointed toward a more complete transformation of European society; in class terms the growing proletariat of industrial workers, increasingly organized and united to secure economic gains, provided the political base for such a transformational project.

Marx entered the European political scene in the eighteen-forties with a well developed materialist theory of history, which saw class control of social 
surplus production through exploitative social relations as the mainspring of political and social change. His political work centered on the (somewhat quixotic) goal of persuading the European proletariat to make change in the class control of social surplus product the content of its program. Marx and his allies had some success in this direction: European politics of the late nineteenth and early twentieth centuries did become obsessed with the relation of the market and state and with mechanisms for sharing the wealth created by industrial capitalism through redistribution. The politicians of the European Left had less luck in transferring control of economic production from the capitalists to bureaucrats, despite some valiant attempts, particularly in the ruins of a Europe shattered by the Second World War.

Marx's revolutionary communism thus was grounded in a hard-headed realistic analysis of European politics and society in his own time. The economically radical aspect of Marx's project was the idea that the proletariat would wrest control of the social surplus product from industrial and financial capitalists. Initially the proletariat would control the surplus product as a class (presumably exploiting itself in the fashion outlined in the Critique of the Gotha Programme), but with the longer-run goal of ending exploitation altogether.

Marx branded his socialism "scientific", because it grew out of an "objective" assessment of European political history in terms of class, and because it was grounded in the widely accepted conclusions of classical political economy. There is some originality (or possibly incoherence) in Marx's thinking in this respect, since it is not obvious that social control over production is necessarily the economic content of a working class political movement, nor that there is anything in the logic of classical political economy that would lead to the transcendence of private property as the keystone of economic organization.

Marx seems to have had the "vision" that one end of this conundrum would supply the solution to the other. As I have argued (Foley, 2006, ch 3) Marx did see that the combination of Smithian increases in the usevalue productivity of labor due to the extension of the division of labor and Malthusian pressures keeping wages close to subsistence would lead to an unbounded rise in the rate of exploitation. ${ }^{1}$ This trajectory of capitalist

\footnotetext{
${ }^{1}$ If $x$ is the use-value productivity of labor, and $w$ the use-value equivalent of the wage, then the rate of exploitation is $e=(x-w) / w$ Foley and Michl (see 1999); if $w$ stagnates at subsistence while $x$ rises the rate of exploitation increases without limit.
} 
accumulation does pose some purely economic problems, mainly the question of where the aggregate demand to realize the potential product will come from; but it raises the even more explosive political question of how the small minority of capitalists can repress a working class which is so productive and sharing so little in the fruits of its own productive powers.

The question of why a revolutionary European workers' movement would adopt a program of social control of production proved somewhat more challenging to Marx's genius for theoretical speculation. I will address this question in section 2 .

The historical evolution of capitalist accumulation resolved the problem of the unbounded rise in the rate of exploitation in the frustratingly practical compromise of an increase in the use-value equivalent of wages at roughly the same rate as the increase in the use-value productivity of labor. This pattern, with interruptions, was sustained from the mid-nineteenth century to the nineteen-seventies; it asserted itself in a remarkably wide range of contexts for industrial capitalist accumulation, from Europe to North America to Asia. Since nineteen-eighty median real wages have ominously stopped rising at the rate of increase of labor productivity in the advanced capitalist economies; in fact, median real wages have become stagnant.

Marx realized that the general rise of wages posed a fundamental problem for his revolutionary socialist program, since it could be argued (as Smith had already realized and innumerable later apologists for capitalism have repeated) that capitalism was as good or better a vehicle for sharing increases in the productivity of labor as socialism. This "trickle-down" ideology remains the bedrock of bourgeois political economy. Marx replaced the vision of an unbounded increase in the rate of exploitation (too much surplus value) with the more subtle and convoluted theory of the falling rate of profit (too little surplus value relative to the value of capital), discovering the pattern of capital accumulation Thomas Michl and I have called "Marx-biased technical change", which fits a wide range (but not all) capitalist economies undergoing industrialization.

\section{The Grundrisse and labor money}

The problem of persuading the European working class movement to adopt a program of socialization of production was a life-time challenge to Marx. He faced a range of committed and credible working-class political leaders whose 
economic programs fell far short of Marx's vision of epochal change (the end of mankind's prehistory), which would sweep away not only exploitative wage-labor relations, but commodity and money forms of organization of the division of labor as well. The ideas of Marx's political rivals aimed in one way or another at retaining the commodity and money forms of the organization of the division of labor while somehow eliminating exploitation. ${ }^{2}$

One influential proposal along these lines was the idea of replacing money with labor certificates (as put forward by the "Ricardian socialists" Bray and Gray). Marx devotes the massive Chapter on Money in the Grundrisse (Marx, 1973, Chapter on Money) to a detailed analysis of this idea. An uncritical reading of Ricardo's summary of the theory of value lends some plausibility to the labor money proposal. Ricardo argues that competition tends to force "natural prices" (the long-term average prices around which short-term observed "market prices" fluctuate) to be proportional to the labor time required for the production of commodities. Thus commodity exchange boils down on average to an exchange of labor time for labor time (in the form of particular commodities). Ricardo regards money as a "veil" that only serves as a medium of exchange obscuring this underlying metabolism of the division of labor. So it is tempting to argue for short-circuiting this process by a system that gives workers claims on the total product (labor certificates) equal to the labor time they expend. On average this should work because the amount of labor certificates issued will just match the labor expended and the value created in the mass of commodities produced. But by eliminating the mediation of the capitalist employer, the system would be free of exploitation: workers would receive a full equivalent in labor certificates and claims on the social product for the labor time they actually expended.

Marx's evolving theory of value (an elaboration of the theories of Smith and Ricardo) was particularly directed at ferreting out fallacies in arguments of this type. In the discussion in the Grundrisse Marx centers his critique of the labor-certificate scheme on the observation that under capitalist relations of production private labor becomes social labor only through the exchange of products as commodities. The fallacy of the labor certificate scheme lies in its implicit assertion that private labor could be "immediately" social.

When we unpack this language, we see that Marx is raising a series of

\footnotetext{
${ }^{2}$ These proposals hoped to make $w$ equal to $x$, thus driving the rate of exploitation to zero.
} 
fundamental questions that are still fresh. One point is that commodity exchange equalizes labor times of different workers only on average over repeated cycles of production. In any particular cycle of production market prices and wages may diverge substantially from the natural levels that competition enforces. A second point is that the social character of privately expended labor has to be proved through the realization of the value of the produced commodity through its exchange for money. A third point is that the capitalist extracts labor from labor-power: the capitalist pays the money wage for labor-power, which may be wasted or ineffectual in the production process. This last observation underlines the fact that the wage-labor contract, though it results in workers appropriating a "share" of the value produced in the form of wages, is not a contract to share the value produced. The capitalist buying labor-power pays the wage whether or not any value is produced at all.

This line of thinking has important ramifications for the understanding of money as what Marx later called the "socially accepted general equivalent": labor in actual production is always concrete and private and can express itself as abstract and social labor only through the one-dimensional purely quantitative medium of money. It is true enough that when the dust settles, that is, ex post, money prices of commodities average out to consistent quantities of social labor expended, but one cannot expect to achieve this ex post rationality ex ante through the labor certificate scheme.

The conclusion Marx draws from this analysis is that the labor-certificate issuing "bank" would inescapably have to take charge of organizing the production process, not just at the level of individual production sites, but for the economy as a whole.

Curiously enough, Marx more than once arrives at the end of a critique of an argument in the posture of endorsing the argument. In this case Marx starts by critiquing the labor-certificate scheme, but winds up concluding that it would imply the kind of "rational" and "social" (and, it is hard to avoid inferring, "centralized") organization of production he himself advocates.

\section{Marx as a long-period theorist}

Marx spent a lot of time reading and commenting on the classical political economists. Much of his and later readers' attention has centered on his critique of the treatment of surplus value and exploitation in the classical 
political economists. As a consequence, how much Marx accepted the methods and conclusions of the classical political economists in some important areas has not been fully appreciated. One of these areas is Marx's adoption of the "long-period" method of the classical political economists, an issue which has implications for the theory of socialism.

The classical political economists' paradigmatic question was to understand abstractly how a decentralized, competitive market process based on free economic decisions by producers could organize production with a highly developed division of labor. Their analysis of this question is remarkably subtle and insightful, and is the basis of Marx's approach to the same problems.

It is important to realize in discussing this method that it is an abstract thought-experiment, not an attempt to explain the actual workings of real-world economies directly. In reality, for example, producers are not completely free to move between different lines of production, and markets are not completely open to all producers. I have commented on this theory in Foley (2006, ch 1, 2, and 3), and on Marx's adoption of it in Foley (2011). Marx's most complete discussion of these issues appears in the first two Parts of Volume III of Capital (Marx, 1981, Parts I and II).

The long-period method addresses both the problem of the allocation of social labor time among various productive activities and the dynamics of price determination on markets. Market prices of reproducible commodities fluctuate both in time and space, but the long-period method argues that they are regulated by the free movement of producers among lines of production to "gravitate" around "natural prices" (which Marx calls "prices of production"). The basic idea is that if market prices of one type of commodity remain high enough on average for a long time to give producers of that commodity some net perceived advantage over producers of other commodities, that producers will shift into that line of production, which will tend to reduce average market prices there. Thus the natural prices around which market prices gravitate must tend to equalize the perceived advantages to producers in each line of production. One simplified version of this process assumes that the only important respect in which the advantages of producing commodities differ is the labor time required for their production. Under this assumption the natural prices of commodities will tend to be proportional to labor times. The mechanism that enforces these tendencies is a constantly changing social allocation of productive labor to match production to social demand. The long-period method is simultaneously a theory of commodity prices and a theory of the allocation of social labor. (When 
means of production have been appropriated as capital, the movement of producers among lines of production will be regulated by capitalists seeking the highest rate of profit so that natural prices will tend to equalize profit rates. In this situation the free mobility of labor continues to enforce the equalization of the rate of surplus value or exploitation in various lines of production (Cogliano, 2010).)

There are many notable implications of the long-period analysis of commodity production. From the point of view of the problem of socialism the most salient is that the long-period method envisions commodity production as a chaotic, decentralized process of social allocation of productive resources which never reaches a stable equilibrium. In the language of modern complex systems theory the long-period method of the classical political economists regards the production of commodities as an adaptive, self-organizing "bottomup" system. Marx understood this view very thoroughly, and in fact used it to critique commodity-producing capitalism on the grounds of its "anarchic" character. We can see the continuity of Marx's views between his critique of the labor-certificate scheme and the notes that constitute the first two Parts of Volume III of Capital.

Implicitly and on occasion explicitly, Marx viewed socialism as an alternative to commodity-producing capitalism not just in the dimension of exploitation through the wage-labor contract, but also in the more fundamental dimensions of commodity exchange and money. Marx's continuing critiques of the commodity form, ranging from his early essays on alienation to the last part of Chapter I of Volume I of Capital on "commodity fetishism" support this view.

Did Marx have a vision of socialism or communism as methods of organizing production? If so, was it based on what we would now call a top-down or a bottom-up dynamic?

\section{Marx's socialism}

The most complete discussion of the problems of organizing production in a socialist society we have from Marx is the Critique of the Gotha Programme (Marx, 1970), a commentary Marx wrote in 1875 on a draft program for a revived unified workers' movement in the form of a German Social Democratic Party (see Foley, 2006, ch 3 for more discussion).

In general Marx responded to questions about his views on the organiza- 
tion of socialist society by saying that these questions could be solved only by those who actually confronted them historically, that is, presumably, by the revolutionary movements that would establish socialist institutions. This is a prudent and in some ways sensible stance, but frustrating to a posterity that has made notably little progress on these problems.

In the Critique of the Gotha Programme Marx envisions two "stages" to the construction of communism. In "the first phase of communist society as it is when it has just emerged after prolonged birth pangs from capitalist society" Marx describes a situation strikingly like his analysis of capitalist society: workers receive only a part of the value they produce (the rest being reserved for social purposes like investment, education, and administration that are financed out of surplus value in capitalist society). What seems to be the crucial difference is that in capitalist society the surplus product is appropriated by the capitalist (and landowning) classes in the form of surplus value, while in the first stage of socialist society the surplus product is appropriated through some political mechanism, perhaps the "dictatorship of the proletariat". Marx does not explicitly discuss the social organization of production, but we might infer that workers go to jobs in enterprises, get paid in the form of money, and buy products with these money revenues. This is not dramatically different from the way capitalism works. It is interesting that Marx presents himself in these comments as representing a hard-headed realistic "economistic" position which acknowledges resource constraints and the necessity of making decisions subject to social trade-offs.

It seems to me significant that Marx does not seem to raise the issue of the mechanics of control over social production, allocation, or distribution in these passages, despite his evident understanding that commodity production regulates both the allocation of social labor and prices. There is in particular no sign that Marx thought about "market socialist" institutions in which some elements of commodity production, such as competition for sales, might co-exist with workers' direct or indirect control of enterprises.

This lacuna in the discussion of first stage of transition from capitalism to communism is underlined by the language in the Critique of the Gotha Programme Marx produces to discuss communism:

In a higher phase of communist society, after the enslaving subordination of the individual to the division of labor, and therewith also the antithesis between mental and physical labor, has vanished; after labor has become not only a means of life but life's 
prime want; after the productive forces have also increased with the all-around development of the individual, and all the springs of co-operative wealth flow more abundantly - only then can the narrow horizon of bourgeois right be crossed in its entirety and society inscribe on its banners: From each according to his ability, to each according to his needs!

What is particularly interesting about this famous passage is that it focuses so much on the problems of social psychology of labor and the principles of distribution without even a slight reference to mechanisms of social organization of production or the regulation of a division of labor. The invocation of higher productivity as a context in which the problems of productive organization might be easier to resolve is particularly troubling: the springs of cooperative wealth flow much more abundantly today than in 1875 , without much noticeable movement to non-capitalist systems of allocation and distribution.

The hints we can glean from Marx's enthusiasm for the Paris Commune (which ran a siege economy along politico-military lines) and for joint stock corporations as precursors of the socialization of means of production do not go very far to clear up the basic puzzle. Marx understood as well as anyone of his generation the bottom-up logic of commodity production as a system of allocation of productive resources and distribution, but does not even sketch a parallel socialist solution to these problems.

Any thoughts that Marx might have had some version of decentralized spontaneous organization of production in mind as a basis for socialism run into his unambiguous negative comments on commodity production and money as backward "anarchic", "irrational", or "contradictory". Not for Marx any view that the market represents a higher or transcendent form of social interaction that contains at least the seeds of a democratic, decentralized social method of information aggregation.

\section{Collectivist analysis of socialism}

In the years after Marx's death the Italian economists Wilfredo Pareto and Enrico Barone took up the problem of the social organization of production. Pareto and Barone wrote from a technocratic perspective, apparently in the hope of decoupling the debate over socialism from the class struggles that 
were threatening to tear European society apart in the first years of the twentieth century. Barone frames the issue of social control over production as a problem of allocation and distribution, and concludes that the goal of a socialist economy in these dimensions ought to be to mimic the allocation of a purely competitive capitalist economy. The basic idea here is to find a set of prices, including wages, interest rates, and rents, at which individual enterprise marginal costs will faithfully represent real social marginal costs. Costminimizing production at such prices is socially efficient (Pareto-optimal). In principle goods ought to be allocated to households or individuals to equalize these social prices to marginal rates of substitution (ratios of marginal utilities). The simplest way to accomplish this is to give each household or individual an income budget and let them spend it as they prefer. The distribution of these incomes over final household consumers is a political question, to be settled outside the allocation process.

In this setting, as Paul Samuelson later observed, it doesn't really matter whether capital hires labor or labor hires capital, or both are allocated by a central planner: the important goal is the allocation of productive resources and final products consistently with the principle of equating marginal cost and marginal benefit. Marx's social relations of production don't seem to matter from this point of view: except for distribution of income, socialism and competitive capitalism boil down to the same principles of allocation. The decisive rhetorical maneuver in Barone's work is the assertion that economic allocation of resources is a technical rather than political question; or equivalently, that the management of economic policy ought to be left to experts except possibly for the distribution of income. This conclusion has been particularly congenial to the mindset of engineers who tend to view economics as a problem of optimal design and control, rather like a complex industrial production process.

Barone's and Pareto's thought had only a marginal influence on practical political economy, but an enormous impact on the development of economic theory.

\section{Really existing socialism}

History, of course, was not waiting for political economy to sort out the issue of socialism. The early decades of the twentieth century also saw the emergence of a Soviet Union dedicated, rhetorically at least, to the building of 
a socialist economy, out of the wreckage of the Russian Empire. ${ }^{3}$ The Bolsheviks confronted two practical political economic problems in the 1920s. Perhaps the lesser was the organization of day-to-day production and distribution. The greater was what later came to be called the problem of "development": how to transform the backward, largely traditional agricultural economy of the sprawling Russian empire into a viable industrialized power. The second task was all the more pressing because the dénouement of the First World War on the Eastern Front had revealed the military and political vulnerability of a backward Russian economy in a world increasingly populated by industrialized capitalist powers.

The Soviets, whose leadership contained some remarkably talented and thoughtful figures, such as Nikolai Bukharin, arrived at a practical solution to the problem of organization of day-to-day production fairly soon after consolidating political power through prevailing in the Civil War with the Whites. This took the form of the "New Economic Policy" (NEP), which allowed, and indeed encouraged, capitalist commodity production in many sectors of the economy, including food production. The NEP structurally created a "mixed" economy in which a large private sector co-existed with state-sponsored industrial enterprises. (The NEP is recognizably a precursor of Deng Xiaoping's "socialist market economy" which was the framework for Chinese economic growth in recent years.) The NEP worked well to stabilize the Soviet economy after the Civil War; under this regime output and incomes recovered significantly from the low levels of the Civil War period. Many Bolsheviks, including Lenin, were willing to accept the NEP framework as an indefinitely prolonged phase of building socialism, as long as the state held the "commanding heights" of the economy through control of energy, transportation, heavy industry, and finance.

Two connected and predictable developments undermined the NEP. First, as we would expect, the privatized commodity-producing sector of the economy exemplified some fundamental laws in generating large disparities in income and wealth. The appearance of a wealthy proto-bourgeoisie in the midst of a society governed by a one-party dictatorship committed to socialist goals threatened the narrow political base of Bolshevik power. Second, the NEP was structurally favorable to the agricultural sector, particularly to

\footnotetext{
${ }^{3}$ The bitter and still acrimonious political controversies over the Soviet experiment make it very difficult to learn just what happened. The reader interested in exploring this subject might start with Carr (1985); Nove (1989); Ellman (1989).
} 
the market-oriented strata of the peasants. The NEP thus resulted in a relatively "balanced" path of economic growth between industry and agriculture. Not surprisingly the prices of food and other agricultural products tended to rise relative to industrially produced goods, limiting the degree to which surplus production in agriculture could be mobilized for rapid industrial investment. Despite Bukharin's determination to "ride to socialism behind the peasant's nag", NEP policies proved explosively unstable politically, and collapsed under efforts to mobilize agricultural surpluses by military force which ultimately led to collectivization, central planning, and the bloody political purges of the nineteen-thirties. Stalin rather than Bukharin balanced at the top of the "greasy pole" of Communist Party politics apparently more by ruthless and opportunistic manipulation of coalition politics than through consolidating a stable political base of power.

Just how the Soviet economy did operate in the 1930s, and in particular what was the practical mixture of bottom-up and top-down dynamics in this period remains obscure. A relatively small central planning bureaucracy had in theory enormous economic power to implement a policy of extremely rapid industrialization centered on the expansion of heavy industry. It seems unlikely that the fairly coarse-grained plans produced could be the whole story of Soviet economic life under this regime. The management of new industrial armies recruited to new urban centers involved a great deal of decentralized local improvisation and experimentation. Since the centralized planning bureaucracy did not actually control many resources itself, local managers facing shortages of inputs and surpluses of outputs improvised informal market-like arrangements with each other. Despite the wishful thinking of market-fundamentalists, capitalist economies in periods of extremely rapid industrialization have often strayed significantly from the orthodoxies of profit-maximization given market prices, making it difficult to draw hard analytical lines by which to characterize the Soviet experiment.

\section{The socialist calculation debate}

While the Soviets were engaged in their furious (if in the very long run curiously futile) attempt to change the world, western European philosophers continued to interpret it. The Bolshevik impulse spilled over into active revolutionary movements in Hungary and other parts of Europe. The bright confidence of bourgeois ideology was shaken by the debacle of the First World 
War, and the post-War political regimes in European countries were fragile and weak-willed, and thus ready to compromise with elements of Bolshevism and statism.

The "Austrian" school of neoclassical economics, founded by Carl Menger, and bolstered by Eugen von Böhm-Bawerk's critique of Marx's theory of value, founded itself on a belief in the existence of universal economic laws. (From a Marxist point of view these "universal" laws look very much like the laws of commodity production, which underly the logic of market exchange.) The flirtation of the European political elite with the idea of fundamental changes in economic organization along socialist lines disturbed the Austrians deeply. Ludwig von Mises was moved to argue (von Mises, 1990) that centrally planned socialism was an impossibility. Mises' case was that economic rationality required determining market-clearing prices for the millions of specific goods and services offered. This task, he argued, was beyond the capacity of any central planning mechanism on purely computational grounds. (An irony of history is that at the same time Mises was formulating this argument, Alan Turing and others were laying the theoretical groundwork for the creation of electronic computers which could practically tackle problems of this magnitude.)

Oskar Lange and Abba Lerner (Lange, 1948; Lerner, 1970) cleverly (perhaps overly cleverly) proposed to turn this argument on its head: why couldn't a socialist society (along the lines of Barone's analysis) mimic a capitalist commodity society by instructing the socialist managers of enterprises to compete on markets like capitalism firms? In this way the sacred equalities of efficient allocation (between marginal costs and prices) could be discovered by a socialist economy.

This was an ingenious but, as it turned out, quite perilous move. By endorsing the idea that the comparison of socialism and capitalism could legitimately be reduced to a comparison of allocation of resources and distribution, this argument for the feasibility of market socialism undermined the argument for any type of socialism. This phase of the socialist calculation debate played a powerful role in shaping general equilibrium theory by legitimating the view that the theory of resource allocation was a neutral territory for political economy, an arena in which bourgeois and socialist scientists could coexist and carry out Popperian dialogue under a Durkheimian blessing. This turn of events explains the peculiar structure of economic general equilibrium theory, which abandons the substance of the neoclassical vision in a pursuit of empty mathematical generality (see Mandler, 1999, for 
a thoughtful exploration of these themes).

The version of economic dogma, enshrined in the "First and Second Fundamental Welfare Theorems" and "Fundamental Existence Theorem" around which mainstream economics built its texts, curriculum, and worldview in the last half of the twentieth century is technically flawed (see Foley, 2010, for a detailed discussion) in ignoring the dependence of final market allocations on the path of transactions.

The First Welfare Theorem is usually phrased in laissez-faire language to assert that a competitive market equilibrium in the absence of externalities is a Pareto-optimum; a less-mystified statement would be that private commodity owners free to make arbitrary voluntary exchanges, will continue trading to some allocation close to or in the private exchange equilibrium set in which their private reservation prices for the commodities are all equal. (The reasoning behind this conclusion is simply that if private reservation prices at any allocation are not equal, then transactions the agents view as mutually advantageous are possible, and will be carried out.) ${ }^{4}$

The Second Welfare Theorem is usually presented as arguing that when preferences and production sets exhibit diminishing marginal rates of substitution and transformation (in mathematical language when utility and production functions are concave) any Pareto-optimal allocation can be implemented as a competitive market equilibrium with an appropriate redistribution. In this form the Second Fundamental Welfare Theorem has a political corollary: since capitalist commodity production can in principle achieve the same range of outcomes as any socialist alternative, the advocates of socialism might as well pursue the goal of redistribution under capitalist social relations. In fact, from a certain point of view socialism and the redistribution of resources under capitalism amount to the same thing. The flaw in the Second Welfare Theorem lies in its ignoring the path-dependence of competitive equilibrium allocations on the transactions that implement it. In general if some omnipotent authority were to reallocate ownership of resources among the members of a society in accordance with some principle of distributional equity, the process of market trade to the exchange equilibrium set would introduce additional horizontal inequality into the final distribution of produced goods and services. (The only way this market-generated

\footnotetext{
${ }^{4}$ The private exchange equilibrium set is the Pareto-optimal locus in the absence of externalities, because without externalities private reservation prices for commodities coincide with social marginal benefits and costs.
} 
inequality could be avoided would be for the omnipotent authority to enforce the final allocation of goods and services directly - shades of Marx's critique of the labor-certificate bank!)

The larger fallacy in the whole socialist calculation debate, however, lies in its complacent acceptance of the idea that the only thing that matters in a society is the production and distribution of material goods and services. In Marx's language this is roughly the position that it is possible to understand the development of "forces of production" independently of "social relations of production". At this very abstract level, reducing the comparison of capitalism and socialism to points in an Edgeworth-Bowley box is just another way of asserting the existence of "universal" economic "laws" independent of the form of social organization of production. Marx hammers away at this fallacy repeatedly: means of production become "capital" only when they are appropriated as private property; the natural productive powers of the natural environment become "land" only when they are appropriated; "labor" is quite a different category depending on whether we are talking about slave labor, "free" wage labor, or the "labor of freely associated producers". The real import of the historical social choice between socialism and capitalism is precisely what is left out of the socialist calculation debate: the social relations through which people organize themselves to produce.

\section{Hayek changes the ground}

For Friedrich Hayek Lange's riposte to Mises' claim of the economic impossibility of socialism was an Archimidean epiphany (summarized in von Hayek, 1948, particularly Essays IV, VII, VIII, and IX). It would be impossible for the managers of socialist enterprises, Hayek argues, to mimic capitalist competition because the socialist manager would not be putting his or her own personal interests in play in making production and investment decisions. (Insofar as the socialist State tried to remedy this problem by creating "incentive compatible" systems in which managers' personal interests were aligned with profit-maximization, the socialist State would be reproducing capitalist social relations. Shades of the NEP and the Deng Xiaoping!)

The implications of Hayek's critique, however, go far beyond the tired dialectics of market vs state. In Hayek's more radical view, commodity production expresses the existential content of human social existence. Each of us inevitably understands a different aspect of the world: as a result there 
can be no centralized representation of human knowledge in the large sense. Only through somehow reassembling the bits of knowledge scattered through the whole population can social production take place. But, in Hayek's way of thinking, people will surrender their individual knowledge to society only as part of a deal that touches their self-interest. Marx's story of social production without commodities and money is doomed to remain a fantasy, because properly understood social production is commodity production. It is only through commodity exchange that the information flows required to sustain social production can be elicited and recombined.

Hayek's insight is bound to be compelling to people who live with and by computers, the internet, and the stock market. It does seem increasingly true that economic life is an exchange of information, not the metabolism of material production and distribution. (On the other hand these same people do continue to eat food, live in houses, wear clothes, and drive cars. The nutritional value of a megabyte of computer code is hard to detect.) Hayek represents an important turning point in our conceptualization of social life, leading to regarding human societies as complex, adaptive systems.

The blind spot in Hayek's thinking is the complete neglect of distributional issues. This is no accident: in fact, it is a principled and consistent implication of his social theory, in which process is privileged over outcomes. The important thing about markets (or in the broader sense commodity exchange) for Hayek is the process of revelation of information. This process may have as a by-product the production and consumption of material goods and services, but that is not its main purpose. Humanity is defined by information revelation as much as by language or sociality, both of which can, of course, be viewed from an information perspective.

In some ways Hayek's intervention returns us to the perspective of the classical political economists. Despite Marx's attempt to hijack the theoretical power of classical political economy as a vehicle for revolutionary socialist transformation, Smith and Ricardo express no discomfort with commodity relations, though they do see commodity production as a complex system. As far as one can tell from their writing, Smith and Ricardo see humanity as finding its fate in the framework of commodity production, not outside of it.

But the idea of socialism is as closely intertwined with capitalist commodity production as bourgeois ideology, and is not much more likely to be conjured away by dialectics alone. 


\section{References}

Carr, E. H. (1985). Bolshevik Revolution, 1917-1923. W.W. Norton, New York.

Cogliano, J. (2010). Smiths perfect liberty and Marxs equalized rate of surplus-value. Submitted.

Ellman, M. (1989). Socialist planning. Cambridge University Press, Cambridge [England] ; New York.

Foley, D. K. (2006). Adam's Fallacy: A Guide to Economic Theology. Harvard University Press, Cambridge, MA.

Foley, D. K. (2010). What's wrong with the fundamental existence and welfare theorems? Journal of Economic Behavior and Organization, 75:115131.

Foley, D. K. (2011). The long-period method and Marx's theory of value. In Caspari, V., editor, The Evolution of Economic Theory: Essays in Honour of Bertram Schefold, pages 15-38. Routledge, Abington and New York.

Foley, D. K. and Michl, T. R. (1999). Growth and Distribution. Harvard University Press, Cambridge, MA.

Lange, O. (1948). On the economic theory of socialism. The University of Minnesota Press, Minneapolis.

Lerner, A. P. (1970). Economics of control; principles of welfare economics. A. M. Kelley, New York.

Mandler, M. M. (1999). Dilemmas in Economic Theory: Persisting Foundational Problems in Microeconomics. Oxford University Press.

Marx, K. (1970). Critique of the gotha programme. In Marx/Engels Selected Works, volume 3, pages 13-30. Progress Publishers, Moscow. 1875.

Marx, K. (1973). Grundrisse: Foundations of the critique of political economy (Rough Draft). Penguin, Harmondsworth.

Marx, K. (1981). Capital, volume 3. Penguin Books, London and New York. [1894]. 
Nove, A. (1989). Economic history of the U.S.S.R. Penguin Books, Harmondsworth, Middlesex, England ; New York, N.Y., U.S.A.

von Hayek, F. (1948). Individualism and Economic Order. University of Chicago Press, Chicago.

von Mises, L. (1990). Economic calculation in the socialist commonwealth. Ludwig Von Mises Institute, Auburn University, Auburn, AL. translated from the German by S. Adler. 